\title{
Pengaruh pemberian klorofilin berbagai dosis terhadap indeks fagositosis makrofag dan kadar nitric oxide mencit BALB/c yang diinfeksi dengan Salmonella typhimurium
}

\author{
Puspito Arum¹, Lisyani B Suromo², Niken Puruhita ${ }^{3}$
}

\begin{abstract}
Background: Immune responses to eliminate Salmonella infection are by activating macrophage and by producing NO. Chlorophyllin is a chlorophyll derivate that has immunomodulator properties.

Objective: The aim of this study was to prove effect of chlorophyllin in macrophage phagocytosis index and NO level.

Methods: A post test only controlled group design was conducted in 5 groups Balb/c mice (negative control, positive control, dosage $100 \mu \mathrm{g} / 200 \mathrm{~g} \mathrm{BW}$, dosage $200 \mu \mathrm{g} / 200 \mathrm{~g} \mathrm{BW}$ and dosage $380 \mu \mathrm{g} / 200 \mathrm{~g} \mathrm{BW)}$. Macrophage phagocytosis index was measured by counting cells that phagocyte latexs particles. NO level was measured by Griess method. Macrophage phagocytosis index difference was analyzed by one way anova and NO level deference was analyzed by Kruskall-Wallis test ( $\alpha$ 0,05).

Results: Means of macrophage phagocytosis index were $0,7( \pm 0,80), 1,8( \pm 0,80), 2( \pm 0,22), 2,5( \pm 0,43)$ and $3,2( \pm 0,68)$ respectively in negative control, positive control, chlorophyllin dosage $100 \mu \mathrm{g} / \mathrm{g}$ BW/day, $200 \mu \mathrm{g} / \mathrm{g}$ BW/day and $380 \mu \mathrm{g} / \mathrm{g}$ $B W / d a y$. There was a significant difference of macrophage phagocytosis index between group (p 0,000). Mean of NO level were $0,4 \mu M( \pm 0,10), 0,6 \mu M( \pm 0,60), 0,8 \mu M( \pm 0,64), 0,6 \mu M( \pm 0,67)$ and $0,4 \mu M( \pm 0,26)$ respectively in negative control, positive control, chlorophyllin dosage $100 \mu \mathrm{g} / \mathrm{g}$ BW/day, $200 \mu \mathrm{g} / \mathrm{g}$ BW/day and $380 \mu \mathrm{g} / \mathrm{g}$ BW/day. There was no difference of NO level between group (p 0,813).

Conclusion: There was a significant difference of macrophage phagocytosis index between chlorophyllin administered group and control. The higher chlorophyllin dosage, the higher macrophage phagocytosis index. Therewas no difference of NO level between chlorophyllin administered group and control.
\end{abstract}

Keywords: chlorophyllin, macrophage, NO, Salmonella typhimurium

\section{ABSTRAK}

Latar Belakang : Respon imun tubuh terhadap infeksi Salmonella diantaranya mengaktifkan makrofag dan produksi NO. Klorofilin merupakan turunan dari klorofil yang memiliki sifat sebagai immunomodulator.

Tujuan : Tujuan penelitian ini membuktikan pemberian klorofilin berbagai dosis berpengaruh terhadap indeks fagositosis makrofag dan kadar NO.

Metode : The post test only controlled group design pada mencit Balb/c terbagi dalam 5 kelompok. Perbedaan indeks fagositosis makrofag dianalisis menggunakan uji one way anova. Perbedaan kadar NO diukur menggunakan dianalisis menggunakan uji Kruskall-Wallis.

Hasil : Rerata indeks fagositosis makrofag 0,7( $\pm 0,80), 1,8( \pm 0,80), 2( \pm 0,22), 2,5( \pm 0,43)$ dan 3,2( $\pm 0,68)$ masing-masing pada

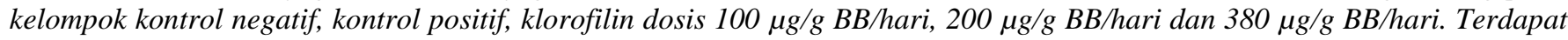
perbedaan rerata indeks fagositosis makrofag (p 0,000). Rerata kadar NO 0,4 $\mu M( \pm 0,1), 0,6 \mu M( \pm 0,60), 0,8 \mu M( \pm 0,64), 0,6$ $\mu M( \pm 0,67)$ dan 0,4 $\mu M( \pm 0,26)$ masing-masing pada kelompok kontrol negatif, kontrol positif, klorofilin dosis $100 \mu g / g$ BB/hari, dosis $200 \mu \mathrm{g} / \mathrm{g} \mathrm{BB/hari} \mathrm{dan} \mathrm{dosis} 380 \mu \mathrm{g} / \mathrm{g}$ BB/hari. Tidak terdapat perbedaan bermakna rerata kadar NO (p 0,813).

Simpulan : Ada perbedaan bermakna pada indeks fagositosis makrofag antara kelompok diberi klorofilin dengan kelompok tanpa klorofilin. Peningkatan dosis klorofilin meningkatkan indeks fagositosis makrofag. Tidak terdapat berbedaan bermakna pada kadar NO antara kelompok diberi klorofilin dengan kelompok tanpa klorofilin.

Kata kunci : klorofilin, makrofag, NO, Salmonella typhimurium

\section{PENDAHULUAN}

Salmonellosis merupakan kejadian yang masih

${ }^{1}$ Program Studi D-IV Gizi Klinik, Jurusan Kesehatan, Politeknik Negeri Jember, Indonesia

${ }^{2}$ Bagian Patologi Klinik, Fakultas Kedokteran, Universitas Diponegoro, Semarang, Indonesia

${ }^{3}$ Bagian Gizi, Fakultas Kedokteran, Universitas Diponegoro, Semarang, Indonesia sering terjadi di seluruh belahan dunia. Demam tifoid menyebabkan terjadinya 21.650 .974 kasus kesakitan dan 216.510 kasus kematian selama tahun $2000 .{ }^{1}$ Diantara negara-negara di Asia, Indonesia merupakan negara dengan insidensi typhoid sedang. ${ }^{2}$

Tahap awal infeksi Salmonella, LPS (Lipopolisakarida) menginduksi terjadinya respon inflamasi pada jaringan disekitarnya dan berakibat pada diproduksinya sitokin-sitokin seperti TNF- $\alpha$, IL- 
1, IL-6, IL-2 dan IL-18 dan berbagai jenis kemokin yang mengundang sel-sel sistem imun untuk datang ke tempat tersebut. Selain itu, juga diproduksi sitokin IFN- $\gamma$ oleh sel NK, makrofag, sel B dan populasi sel T khusus. Produksi IFN- $\gamma$ akan mengaktivasi makrofag untuk melakukan killing bakteri. Makrofag yang teraktivasi akan memproduksi reactive oxigen intermediates (ROIs), seperti superoxide dan reactive nitrogen intermediates (RNIs), utamanya nitric oxide (NO). Kedua molekul tersebut berperan dalam membunuh bakteri dalam fagolisosom makrofag dan menunjukkan aktifitas makrofag dalam membunuh bakteri. ${ }^{3} \mathrm{NO}$ merupakan molekul yang memiliki berbagai peran. Produksi NO berperan penting dalam respon imun bawaan, yaitu untuk melakukan proses killing tumor dan patogen intraseluler. ${ }^{4}$ NO merupakan agen mikrobisidal kuat terhadap mikroorganisme intrasel. ${ }^{3}$

Klorofilin merupakan derivat dari klorofil yang bersifat larut dalam air, dimana ion logam magnesium $(\mathrm{Mg})$ yang terkandung dalam klorofil digantikan dengan ion logam tembaga $(\mathrm{Cu})$, sehingga memiliki sifat yang lebih stabil dibanding klorofil itu sendiri. Klorofilin telah dengan aman digunakan dalam pengobatan selama beberapa tahun., ${ }^{5,6}$ Klorofilin dianggap sebagai suplemen yang dapat mencegah dan bahkan menyembuhkan berbagai macam penyakit, khususnya keganasan, memberikan efek antioksidan, dan menjaga dan memperbaiki kekebalan tubuh. Fungsi klorofilin dalam menjaga dan memperbaiki kekebalan tubuh, klorofilin dapat digolongkan menjadi immunomodulator, namun belum terdapat banyak penelitian yang membuktikan peran klorofilin sebagai immunomodulator, khususnya pada respon terhadap infeksi bakteri. Aktifitas makrofag dapat dilihat dengan meningkatnya fagositosis makrofag dan produksi NO.

Infeksi Salmonella typhimurium pada mencit menunjukkan gejala penyakit yang sama seperti yang terjadi pada manusia yang terinfeksi oleh Salmonella typhi. Infeksi Salmonella typhimurium pada mencit $\mathrm{Balb} / \mathrm{c}$ kemudian dianggap sebagai model eksperimental bagi demam typhoid pada manusia. ${ }^{7}$ Penelitian ini akan menggunakan tiga dosis pemberian klorofilin, yaitu, $100 \mu \mathrm{g} / \mathrm{g}$ berat badan, $200 \mu \mathrm{g} / \mathrm{g}$ berat badan dan $380 \mathrm{mg} / \mathrm{kg}$ berat badan.

Tujuan penelitian ini adalah membuktikan adanya pengaruh pemberian klorofilin berbagai dosis terhadap indeks fagositosis makrofag dan kadar nitric oxide pada mencit Balb/c yang diinfeksi dengan Salmonella typhimurium. Hipotesis penelitian ini adalah klorofilin berbagai dosis dapat meningkatkan indeks fagositosis makrofag dan kadar NO mencit Balb/c yang diinfeksi Salmonella thypimurrium dibandingkan dengan yang tidak diberi klorofilin.

\section{METODE DAN BAHAN}

Penelitian ini merupakan jenis penelitian eksperimental laboratorik dengan menggunakan rancangan the post test only controlled group. Sampel penelitian adalah 30 ekor mencit Balb/c yang dibagi dalam lima kelompok, yaitu dua kelompok kontrol negatif, kontrol positif, kelompok yang diberi klorofilin dosis $100 \mu \mathrm{g} / \mathrm{g} \mathrm{BB} / \mathrm{hari}, 200 \mu \mathrm{g} / \mathrm{g} \mathrm{BB} / \mathrm{hari}$ dan $380 \mu \mathrm{g} / \mathrm{g} \mathrm{BB} /$ hari. Penelitian dilakukan di LPPT (Laboratorium Penelitian dan Pengujian Terpadu) UGM (Universitas Gadjah Mada). Indeks fagositosis dilihat berdasarkan prosentase sel yang memfagosit partikel latex yang dihitung pada 200 sel dikali rerata jumlah partikel yang difagosit pada sel yang positif. Kadar NO diukur dari konsentrasi NO yang terdapat dalam supernatan kultur makrofag yang diukur denga reagen Griess.

Analisis deskriptif digunakan untuk menampilkan rerata dan simpang baku dari indeks fagositosis makrofag dan kadar NO. Uji normalitas data menggunakan Saphiro Wilk. Uji one way anova digunakan untuk menganalasis perbedaan Indeks fagositosis makrofag antar kelompok, dan dilanjutkan dengan uji $L S D$, uji Kruskall Wallis digunakan untuk menganalisis perbedaan kadar NO antar kelompok, dan dilanjutkan denganuji Mann-Whitney, dengan $\alpha$ 0,05 .

\section{HASIL}

\section{Indeks Fagositosis Makrofag}

Indeks fagositosis makrofag dihitung berdasarkan presentase sel yang memfagosit partikel latex dikali rerata jumlah partikel yang difagosit sel yang positif. Berdasarkan uji one way ANOVA, terdapat perbedaan bermakna rerata indeks fagositosis makrofag antar kelompok perlakuan (p 0,000).

Berdasarkan uji LSD (tabel 1), diperoleh kesimpulan bahwa indeks fagositosis makrofag pada kelompok yang diberi klorofilin dosis $380 \mu \mathrm{g} / \mathrm{g}$ BB dan $200 \mu \mathrm{g} / \mathrm{g}$ BB lebih tinggi dibandingkan dengan kelompok yang tidak diberi klorofilin. Tidak terdapat perbedaan indeks fagositosis makrofag pada kelompok yang diberi klorofilin dosis $100 \mu \mathrm{g} / \mathrm{g}$ BB dengan kelompok yang tidak diberi klorofilin (kontrol pisitif). Indeks fagositosis makrofag pada kelompok yang diberi klorofilin dosis $380 \mu \mathrm{g} / \mathrm{g}$ BB lebih tinggi dibanding kelompok-kelompok lainnya.

\section{Nitric Oxide}

Kadar NO diperoleh dari menghitung konsentrasi nitrit dalam sampel berdasarkan kurva standar dari pembacaan nitrit standar.Rerata kadar NO pada berbagai kelompok perlakuan tidak terdapat 
perbedaan bermakna rerata kadar NO antar kelompok perlakuan (p 0,813).

\section{PEMBAHASAN}

Hasil penelitian ini menunjukkan adanya peningkatan indeks fagositosis makrofag pada kelompok yang diberi klorofilin dibanding yang tidak diberi klorofilin. Fagositosis makrofag semakin meningkat seiring dengan peningkatan dosis klorofilin. Hasil penelitian ini sejalan dengan hasil penelitian yang dilakukan oleh Sharmaet $a l^{8}$ yang menunjukkan pemberian klorofilin dosis $100 \mu \mathrm{g} / \mathrm{g}$ $\mathrm{BB} /$ hari dan $200 \mu \mathrm{g} / \mathrm{g} \mathrm{BB} /$ hari dapat meningkatkan aktifitas fagositosis makrofag pada mencit yang diimunisasi dengan SRBC (Sheep Red Blood Cells). Hasil yang sama ini ditunjukkan pada penelitian ini walaupun respon imun dipicu oleh dua hal yang berbeda, Salmonella typhimurium pada penelitian ini dan SRBC pada penelitian yang dilakukan oleh Sharma et al. Pada penelitian ini indeks fagositosis makrofag meningkat karena jumlah makrofag yang memfagosit partikel latex dan jumlah partikel latex yang difagosit semakin meningkat seiring dengan peningkatan dosis klorofilin yang diberikan.

Penelitian ini melihat aktifitas fagositosis makrofag secara in vitro dengan menggunakan latex bead sebagai partikel yang difagosit. Sinyal transmembran akan menyebabkan polimerisasi actin yang ada pada permukaan sitoplasma ketika latex kontak dengan reseptor yang ada pada permukaan makrofag, sehingga terjadi pembentukan fagosom. ${ }^{9}$ Retikulum endoplasma bergerak menuju permukaan sel dan akan bergabung dengan membran plasma di bawah cawan fagositik untuk mensuplai membran pada pembentukan fagosom. ${ }^{10}$

Makrofag, secara in vivo, teraktifasi oleh adanya infeksi Salmonella. Peningkatan aktifitas fagositosis antara lain dipengaruhi keberadaan reseptor yang mengenali antigen, seperti TLR (Tolls Like Receptor), reseptor komplemen dan reseptor Fc $\gamma$. Sel mamalia mengenali LPS dari bakteri gram negatif melalui TLR4 komplek. ${ }^{11}$ TLR4 mengikat rantai acil lipid A pada LPS. Ikatan antara LPS dan TLR4 yang mengaktifkan MyD88 berperan penting dalam mengontrol pertumbuhan exponensial Salmonella typhimurium. ${ }^{11}$ Bakteri mengaktifkan sistem komplemen melalui jalur alternatif. Aktifasi komplemen melalui jalur alternatif akan menyebabkan pemecahan protein komplemen C3. Hasil pemecahan komplemen $\mathrm{C} 3$ akan dikenali oleh reseptor CR1 (type 1 complement receptor). ${ }^{3} \mathrm{CR} 1$ yang berikatan dengan fragmen komplemen $\mathrm{C} 3 \mathrm{~b}$ dan memicu aktifitas fagositosis. ${ }^{11}$ Reseptor Fc $\gamma$ mengenali mikroba yang telah diopsonisasi oleh antibodi. ${ }^{3}$ Interaksi antara reseptor $\mathrm{Fc} \gamma$ dengan antibodi menginisiasi fagositosis, kemudian bakteri yang telah diopsonisasi oleh antibodi ditelan oleh makrofag hingga membran sel makrofag menutupi keseluruhan bakteri. ${ }^{12}$

Klorofilin memiliki efek mampu meningkatkan pembentukan komplemen C3. ${ }^{17} \mathrm{C} 3$ merupakan salah satu faktor yang berperan dalam meningkatkan fagositosis makrofag. Infeksi bakteri mengaktifasi terpecahnya $\mathrm{C} 3$ menjadi fragmen $\mathrm{C} 3 \mathrm{~b}$ yang berperan sebagai opsonin yang kemudian dikenali oleh CR1, sehingga memudahkan fagosit untuk melakukan fagositosis bakteri yang diopsonisasi oleh komplemen $^{11}$ dan $\mathrm{C} 3 \mathrm{a}$ yang berperan sebagai chemoattractant sel neutrofil dan fagosit. ${ }^{2}$ Klorofilin juga mengandung logam $\mathrm{Cu}$ pada tengah cincin porfirinnya. Ion logam $\mathrm{Cu}$ memiliki efek yang besar terhadap neutrofil dan makrofag, dimana defisiensi $\mathrm{Cu}$ menyebabkan terjadinya keadaan neutrofenia. ${ }^{13}$

Penelitian ini hanya melihat hubungan klorofilin dengan aktifitas fagositosis makrofag, namun tidak meneliti faktor lain yang mempengaruhi fagositosis makrofag seperti flora usus. Pemberian Lactobacillus casei dan Lactobacillus bulgaricus terbukti mengaktifkan produksi makrofag dan pemberian Lactobacillus acidophilus mengaktifkan fagositosis pada mencit. ${ }^{14,15}$ Infeksi Salmonella typhimurium mempengaruhi keadaan flora usus. Faktor antimikrobial yang muncul akibat infeksi Salmonella memperlambat pertumbuhan mikrobiota usus dan mengganggu jejaring komensal antar mikrobiota saluran cerna, sehingga menyebabkan Salmonella dapat berkembang dengan bebas. ${ }^{16}$

Hasil penelitian ini menunjukkan kadar NO tinggi pada pemberian klorofilin dosis $100 \mu \mathrm{g} / \mathrm{g} \mathrm{BB}$, namun nilai tersebut tidak memiliki perbedaan yang bermakna dibanding kelompok lainnya. Penelitian oleh Yun, et al menunjukkan klorofilin menurunkan kadar IFN- $\gamma$ melalui penekanan terhadap produksi IL12. IFN- $\gamma$ memiliki peran menginduksi produksi NO oleh monosit dan makrofag. ${ }^{19}$ Penurunan kadar IFN- $\gamma$ berakibat pada penurunan produksi NO. Teori ini sejalan dengan hasil penelitian yang menunjukkan semakin tinggi dosis klorofilin, semakin menurunkan kadar NO.

Klorofillin menunjukkan aktifitas antioksidan terhadap kerusakan oksidatif ${ }^{19,20}$ karena keberadaan ion logam $\mathrm{Cu}$ pada cincin porphyrinnya. ${ }^{22} \mathrm{Cu}$ merupakan komponen dari superoxide dismutase, suatu enzim antioksidan yang penting. ${ }^{23}$ Tubuh memiliki sistem antioksidan enzimatis terdiri dari superoxide dismutase, glutathione peroxidase dan catalase yang bekerja sama dalam eliminasi oksida. ${ }^{24}$

Inflamasi yang terjadi akibat adanya infeksi bakteri menyebabkan diproduksinya oksidan, baik ROS (reactive oxygen species) atau RNS (reactive nitrogen species) yang berperan dalam killing bakteri namun 
juga dapat berakibat pada kerusakan jaringan. Sistem antioksidan enzimatis yang terdiri dari superoxide dismutase, glutathione peroxidase dan catalase berperan dalam mencegah kerusakan jaringan akibat oksidan yang ditimbulkan dari inflamasi. ${ }^{25}$ Adanya ion logam $\mathrm{Cu}$ pada klorofilin meningkatkan aktifitas superoxide dismutase. ${ }^{23}$ Enzim tersebut, pada penelitian ini, diduga mengeliminasi oksidan yang diproduksi oleh makrofag akibat infeksi Samonella typhimurium i.p, sehingga peningkatan dosis klorofilin cenderung menurunkan kadar NO.

Produksi NO dikatalisis oleh iNOS di dalam makrofag dan sel-sel lain yang berperan dalam respon inflamasi ${ }^{26}$ dengan mengubah senyawa L-arginin menjadi L-sitrulin dengan bantuan NADPH, sehingga menghasilkan gas NO. ${ }^{27}$ Produksi NO penting bagi pertahanan non-spesifik, membantu membunuh tumor dan patogen intraseluler. ${ }^{28}$ Peningkatan kadar NO berhubungan dengan aktifitas anti Salmonella. ${ }^{29} \mathrm{NO}$ juga penting dalam mencegah kerusakan jaringan karena memiliki efek antiapoptosis. Peran NO sebagai antiapoptosis melalui mekanisme pembentukan cGMP, penekanan aktifitas cascapes dan menghambat pelepasan sitokrom C. ${ }^{30}$ NO juga telah terbukti melindungi terjadinya kerusakan sel hati akibat Salmonellosis. ${ }^{28}$ Berdasarkan teori, semakin banyak makrofag teraktifasi, maka semakin banyak NO yang akan diproduksi, namun hasil penelitian ini menunjukkan kadar NO yang terbentuk tidak berbanding lurus dengan indeks fagositosis makrofag yang semakin meningkat seiring dengan peningkatan dosis klorofilin.

Penurunan kadar NO juga memiliki efek menguntungkan bagi host karena produksi NO tinggi akan memiliki efek menguntungkan bagi bakteri Salmonella. Efek menguntungkan ini terjadi pada fase infeksi di saluran cerna. Probiotik yang berada dalam saluran cerna memiliki peran dalam aktifitas enzim lysosomal makrofag. ${ }^{15,32}$ Enzim lysosomal elastase berperan dalam eliminasi bakteri Salmonella, ${ }^{31}$ selain killing oleh NO. RNS yang terbentuk pada respon terhadap Salmonella merugikan mikrobiota yang hidup di saluran cerna, sehingga memungkinkan Salmonella untuk berkembang bebas dalam saluran cerna. ${ }^{15,33}$ Berdasarkan teori tersebut, penurunan kadar NO akan menguntungkan bagi mirobiota alami usus sehingga mampu mengaktifasi enzim lysosomal guna membantu proses killing bakteri.

Penelitian ini tidak meneliti pengaruh klorofilin terhadap faktor yang mempengaruhi kadar NO seperti iNOS dan status antioksidan, serta pengaruh klorofilin terhadap jumlah hitung kuman Salmonella.

\section{SIMPULAN}

Peningkatan dosis klorofilin meningkatkan indeks fagositosis makrofag mencit Balb/c yang diinfeksi Salmonella typhimurium. Peningkatan dosis klorofilin menurunkan kadar NO mencit Balb/c yang diinfeksi Salmonella typhimurium

\section{DAFTAR PUSTAKA}

1. Crump JA, Luby SP, Mintz ED. The global burden of typhoid fever. Bulletin of the World Health Organization. 2004; 82(5): 346-353.

2. Ochiai RL, Acosta CJ, Danavaro-Holliday MC, Baiqing D, Bhattacharya SK, Agtini MD, et al. A study of typhoid fever in five asian countries : disease burden and implication for control. Bulletin of the World Health Organization. 2008; 86(4): 260-268

3. Abbas AK, Lichtman AH. Cellular and molecular immunology. Philadelphia: Saunders; 2003.

4. Beckman JS, Koppenol WH. Nitric oxide, superoxide, and peroxynitrite : the good, the bad, and ugly. American Journal Physiology Cell and Physiology. 1996; 271: 1424-1437.

5. Young RW, et al. Use of chlorophyllin in the case of geriatric patients. Journal of American Geriatri and Society. 1980; 28: 46-47.

6. Egner PA, et al. Chlorophyllin intervention reduce aflatoxin-DNA adduct in individual at high risk for liver cancer. US: Procceding National Academy Science. 1980; 98: 1460114606

7. Mittrucker HW, Kaufman SHE. Immune response to infection with salmonella typhimurrium in mice. Journal of Leukocyte Biology. 2000; 67: 457-463.

8. Sharma D, Kumar SS, Sainis KB. Antiapoptotic and immunomodulatory effect of chlorophyllin. Molecular Immunology. 2007; 44: 347-359.

9. Greenberg S, Grinstein S. Phagocytosis and innate immunity. Current Opinion Immunology. 2002; 14: 136-145.

10. Gagnon E., et al. Endoplasmic reticulummediated phagocytosis is a mechanism. Cellular Immunology. 2002; 110: 119-131

11. Beutler B, Du Xi, Poltarak A. Identification of toll-like receptor 4 (TLR4) as the sole conduit for LPS signal transduction : genetic and evolutionary study. Journal of Endotoxin. 2001; 7: 277-9.

12. Baratawidjaja KG, Rengganis I. Imunologi Dasar. Jakarta: Balai Penerbit FKUI; 2010.

13. Percival SS. Copper and immunity. American J. of Clinical Nutrition. 1999; 67: 1064-8 
14. Isolauri E, Sutas Y, Kankaanpaa P, Arvilommi H, Salminen S. Probiotic : effects on immunity. American Journal of Clinical Nutrition. 2001:73(suppl); 444S-50S.

15. Perdigon G, et al. Effect of perorally administered lactobacilli on macrophage activation in mice. Infection and Immunity. 1986: 53 ; 404-410.

16. Stecher B, Robbiani R, Walker AW, Westendorf AM, Barthel M, Kremer M, et al. Salmonella enteric serivar typhimurium exploit inflammation to compete with the intestinal microbiota. PLoS Biology. 2007: 5; 2177-2189

17. Okada H, Nishioke K, Sindo T. The effect of cuchlorophyllin on the active site formation of each component of guinea-pig complement. Immunology. 1969; 16: 473-480.

18. Yun, C. H., et al. Chlorophyllin attenuates IFN- $\gamma$ expression in lipopolysaccharide-stimulated murine splenic mononuclear cells via suppressing IL-12 production. International Immunopharmacol. 2005; 5: 1926-1935.

19. Matsuura., et al. A pathway through interferongamma is the main pathway for induction of nitric oxide upon stimulation with bacterial lipopolysaccharide in mouse peritoneal cell. European Journal of Biochemistry. 2003; 270: 4016-4025.

20. Park KK, Park JH, Jung YJ, Chung WY. Inhibitor effect of chlorophyllin, henim, tetrakis(4-benzoic acid0porphyrin on oxidative DNA damage ang muose skin inlmataion indused by 12-O-tetradecanoylphorbol-13-acetate as a possible anti-tumor promoting mechanism. Mutation. 2003; 542: 89-97.

21. Kumar SS, Shankar B, Sainis KB. Effect of chlorophyllin against oxidative stress in splenic lymphocytes in vitro and in vivo. Biochimica et Biophysica acta. 2004; 1672: 100-111.

22. Lanfer-Marquez UM, Barros RMC, Sinnecker P. Antioxidant activity of chlorophylls and their derivatives. Food International. 2005; 38: 885891.
23. Evan P, Halliwell B. Micronutrient : oxidant/antioxidant status. British Journal of Nutrition. 2001; 85: 67-74.

24. Mates JM, Perez-Gomez C, De Castro IN. Antioxidant enzyme and human disease. Clinical Biochemistry. 1999; 32: 1-9.

25. Conner EM, Grisham MB. Inflammation, free radical, and antioxidant. Nutrition. 1996; 12: 274277.

26. Michel T, Feron O. Nitric oxide synthases : which, where, how, and why?.Journal of Clinical Investment. 1997; 100(9): 2146-2152.

27. Guzik TJ, Korbut R, Adamek-Guzik TA. Nitric oxide and superoxide ininflammation and immune regulation. Journal Physiology and Pharmacology. 2003; 54(4): 469-487.

28. Alam MS, et al. Role of nitric oxide in host defense in murine salmonellosis as a function of its antibacterial and antiapoptotic activities. Infection and Immunity. 2002; 70: 3130-3142.

29. Vazquez-Torres A, Jones-Carson J, Mastroeni P, Ischiropoulos H, Fang FC. Antimicrobial action of the NADPH phagocyte oxidase and inducible nitric oxide synthase in experimental salmonellosis. I. Effect on microbial killing by activated peritoneal macrophages in vitro. Journal of. Experimental and Medical. 2000; 192: 227-236.

30. Kim YM, et al. Nitric oxide as a biofunctional regulator of apoptosis. Infection and Immunity. 1999; 84: 253-256.

31. Korkmaz B, Horwitz MS, Jenne DE, Gauthier F. Neutrophil elastase, proteinase, ang cathepsin $\mathrm{g}$ as therapeutic target in human disease. Pharmacology. 2010; 62(4): 726-759.

32. Alderton WK, Cooper CE, Knowles RG. Nitric oxide synthases : structure, function, and inhibition. Biochemistry Journal. 2001; 357: 593615

33. Henard CA, Vázquez-Torres A. Nitric oxide and salmonella pathogenesis. Microbiology. 2011; 2(84): 1-11. 